\title{
The scid mouse as an experimental model for the evaluation of anti-Pneumocystis carinii therapy
}

\author{
Samuel Kunx*, Ursula Junker", Jurg Blaser", Beda Joos', Barbara Meyer", \\ Oto Zak* and Terence O'Reilly*
}

'Pharmaceutical Research, Ciba-Geigy Limited, Basel, Switzerland, CH-4002;
${ }^{b}$ Department of Medicine, University Hospital, Zurich, Switzerland, CH-8091

The usefulness of scid mice bearing endogenous Pneumocystis carinii infection as a model for experimental chemotherapy was examined using standard compounds known to be effective against $P$. carinii. Trimethoprim/sulphamethoxazole was able to reduce pulmonary $P$. carinii cysts in a dose-dependent manner within the dose range studied (10/50 to $100 / 500 \mathrm{TMP} / \mathrm{SMX} \mathrm{mg/kg/d}$, bd, po, 5 days per week for 30 treatments). However, alterations in associated symptoms of infection (reduced body weight, increased lung weight, increased blood leucocytes and erythrocytes), was apparently not linearly dose-dependent. Blood and lung lavage fluid levels of sulphamethoxazole one hour post administration of trimethoprim/sulphamethoxazole was dose-dependent, but not linear with dose, and was apparently correlated to cyst reduction; trimethoprim was below the limit of detection at this time. Treatment of mice with $100 / 500 \mathrm{mg} / \mathrm{kg} /$ day trimethoprim/ sulphamethoxazole required 2 weeks (bd for 10 days of treatment) before changes in indices of infection became significant. Pentamidine $(20 \mathrm{mg} / \mathrm{kg}$, sc, three times per week for 3 weeks) was nearly as effective as high-dose trimethoprim/sulphamethoxazole in reducing cysts, whereas lower doses were ineffective. Despite being unable to reduce pulmonary $P$. carinii infection, even low doses of pentamidine ( 6 or $2 \mathrm{mg} / \mathrm{kg}$, sc, three times per week for 3 weeks) were able to reduce lung weights and blood leucocyte levels. This model of pulmonary $P$. carinii infections is amenable to chemotherapeutic intervention in an apparently dose-dependent fashion, and can be used to evaluate the capacity of compounds to eradicate $P$. carinii and resolve signs of infection.

\section{Introduction}

Pneumocystis carinii is recognised as a pathogen of immunosuppressed patients and is particularly common in patients suffering from AIDS. Although both experimental and clinical research has demonstrated both trimethoprim/sulphamethoxazole and aerosol pentamidine to be effective agents (Masur et al., 1989; Davey \& Masur, 1990; Bartlett \& Smith, 1991; Smulian \& Walzer, 1992), particularly in primary or secondary prophylaxis, the incidence of failures, development of infections refractory to treatment (especially after inadequate secondary phophylaxis), and severe side-effects, clearly indicate the need for novel therapeutic approaches. Furthermore, recent clinical experience has demonstrated $P$. carinii to be present in extra-pulmonary sites, including

*Corresponding author.

Phone +41-(61)-6963427; Fax + 41-(61)-6962128. 
patients that had received aerosol pentamidine prophylaxis (Dembinski et al., 1990; Telak et al., 1990), and suggests the possibility that this route of pentamidine administration is incapable of suppressing the growth of this organism at distal sites, thus rendering this form of prophylaxis potentially ineffectual in the long term.

The usual in-vivo model for experimental $P$. carinii research is the dexamethasone immunosuppressed rat, which relies on chemical immunosuppression to allow either the growth of endogenous $P$. carinii (Hughes et al., 1974; Kovacs et al., 1988; Masur et al., 1989; Davey \& Masur, 1990), or exogenous $P$. carinii following intratracheal infection (Bartlett et al., 1990; Boylan \& Current, 1992). Cortisone-immunosuppressed mice have also been used (Walzer, Powell \& Yoneda, 1979a; Powles et al., 1992). Although long recognised as an endogenous, lethal infection of genetically immunocompromised mice (Ueda et al., 1977; Walzer et al., 1977; Sundberg et al., 1989), including the severe combined immunodeficient (scid) mouse strain (Walzer et al., 1979a; Shultz et al., 1989), only recently have communications thoroughly describing the pathology of pulmonary $P$. carinii infection in scid mice appeared (Roths et al., 1990; Chen, Mills \& Harmsen, 1992). Recent research has exploited the scid mouse to demonstrate the essential role of $\mathrm{CD}^{+}$(Harmsen \& Stankiewicz, 1990; Roths \& Sidman, 1992), but not CD8 ${ }^{+}$(Roths \& Sidman, 1992) T-cells in resistance to the disease. Furthermore, scid mice have been used to demonstrate the importance of interleukin-1 (Chen et al., 1992) and endogenous tumour necrosis factor, but not interferon $\gamma$ (Chen, Havell \& Harmsen, 1992a) or IL-6 (Chen et al., 1993b), in the resistance to infection. $P$. carinii-infected scid mice have also been used to demonstrate the potential of passive immune therapy (Roths \& Sidman, 1993) and to demonstrate that latent infections may not be the sole source of $P$. carinii in immunocompromised patients (Chen, Gigliotti \& Harmsen, 1993).

However, throughout these studies, little attention has been paid to the suitability of $P$. carinii-infected scid mice for experimental chemotherapeutic intervention. As previous communications indicated the efficacy of trimethoprim/sulphamethoxazole as anti- $P$. carinii therapy in the promotion of survival of scid mice (Walzer et al., 1979a; Shultz et al., 1989), the purpose of the present research was to appraise the $P$. carinii-infected scid mouse as a potential model for the evaluation of novel chemotherapeutic agents. As trimethoprim/sulphamethoxazole and pentamidine are used clinically and as reference agents in experimental studies (Hughes \& Smith, 1984; Clarkson, Williams \& Rosenberg, 1988; Kovacs et al., 1988; Hughes et al., 1990; Bartlett et al., 1991; Brun-Pascaud et al., 1992; Walzer et $a l ., 1992 b$ ), these compounds were used to demonstrate that pulmonary $P$. carinii infection in scid mice is amenable to chemotherapeutic intervention.

\section{Materials and methods}

\section{Scid mice}

Scid mice, proven to be positive for pulmonary $P$. carinii infection by diagnostic microscopy (Giemsa staining of lung histological sections), were housed at Ciba-Geigy. Based upon previous studies (Roths et al., 1990), male or female mice over 90 days of age were obtained for treatment studies. P. carinii free scid mice (from a different colony) were also used. Animals were randomised to treatment groups, marked for later identification and housed in a restricted-access room, in filter-topped cages containing sterilised wood shaving bedding. Animals received autoclaved water and food (double-vitamin) ad libitum. Personnel handling the animals wore "dedicated use" 
laboratory coats, masks and gloves, and cages were only opened under a vertical-flow hood. In two separate experiments, sentinel (DBA) mice housed with the scid mice were screened for the development of antibodies to a variety of viruses (including pneumonia virus of mice; see Bray et al., 1993; Roths, Smith \& Sidman, 1993) and mycoplasma and found to be negative. Determination of possible contamination of the mice with bacteria by culture of lung homogenate and of blood on Brain Heart Infusion agar (Difco) was performed on each mouse. Significant numbers of bacteria were not recovered at any time to suggest bacterial infection to compromise the experiments. The experimental protocols involving animals were approved by the ethics committee of the Kantonales Veterinäramt of Basel Stadt.

\section{Determination of pulmonary $\mathrm{P}$. carinii cysts}

The methods to determine pulmonary $P$. carinii were based upon those described for the collection of cysts from lung homogenates (Walzer et al., 1979c). After the animal was killed ( $0.1 \mathrm{~mL}$ ip T61; Hoechst Veterinarimar), blood was collected from the inferior vena cava into $1 \mathrm{~mL}$ syringes which had been rinsed with EDTA $(10 \% \mathrm{w} / \mathrm{v})$. Lungs were removed intact, weighed, cut into small pieces and then transferred to a glass homogeniser and homogenised in the presence of $150 \mu \mathrm{L}$ of Hanks' buffered salts solution containing $100 \mathrm{U} / \mathrm{mL}$ heparin (Roche). Five $\mathrm{mL}$ of Hanks' solution supplemented with $0.2 \% \mathrm{w} / \mathrm{v}$ collagenase (Boehringer-Mannheim), $0.2 \% \mathrm{w} / \mathrm{v}$ hyaluronidase (Boehringer-Mannheim) and $25 \mathrm{U} / \mathrm{mL}$ heparin was added, and the sample again homogenised. The entire contents were then transferred to a $50 \mathrm{~mL}$ Erlenmeyer flask and incubated with shaking for one hour at $37^{\circ} \mathrm{C}$. The homogenate was then centrifuged $\left(15 \mathrm{~min}\right.$ at $2000 \mathrm{~g}, 20^{\circ} \mathrm{C}$ ), and the pellet (containing $P$. carinii cysts) was resuspended in 100 to $2000 \mu \mathrm{L}$ Hanks' solution containing $100 \mathrm{U} / \mathrm{mL}$ heparin. A $50 \mu \mathrm{L}$ aliquot of this suspension was mixed with $10 \mu \mathrm{L}$ methylene blue (Löffler's; E. Merck product number 1287); the remainder of this suspension could be frozen $\left(-20^{\circ} \mathrm{C}\right)$ without apparent loss of cysts. After 10 min at room temperature, $2 \mu \mathrm{L}$ of the stained suspension was spread across a $7 \mathrm{~mm}^{2}$ square section of clear glass present in a black coated microscope slide (Huber and Co. AG, Reinach, Switzerland) and allowed to dry in air. Three edge to edge lines were evaluated for the number of cysts $(1000 \times$ oil immersion) by at least three independent observers. Previous determination of the number of lines present in the $7 \mathrm{~mm}^{2}$ area (under oil immersion) combined with the known volume of suspension spread within the $7 \mathrm{~mm}^{2}$ area and the original weight of the lung allowed the determination of the numbers of cysts per $g$ (wet weight) of lung homogenate. Depending upon the weight of lung, the limit of detectability was approximately $\log 4 \mathrm{cysts} / \mathrm{g}$ lung. With this methylene blue staining procedure, cysts were stained with a variable intensity of blue, but sufficient to distinguish them from the background material. Some slides were also stained using Toluidine blue or Diff-Quik; using this latter staining method cysts from scid mice demonstrate characteristic morphology (non-staining cyst wall surrounding punctate intra-cyst forms; see Bartlett \& Smith, 1991).

\section{Blood cell counting}

Total erythrocyte and leucocyte cell counts were determined by a Sysmex model CC-170 or E-5000 blood cell analyser (TDA Corp., Kobe, Japan) following the directions of the manufacturer. 


\section{Antimicrobial agents}

Trimethoprim/sulphamethoxazole (Bactrim; Roche) was obtained commercially as sucrose-free syrup containing $16 \mathrm{mg} / \mathrm{mL}$ trimethoprim and $80 \mathrm{mg} / \mathrm{mL}$ sulphamethoxazole and, when necessary, diluted in pyrogen-free saline $(0.9 \% \mathrm{w} / \mathrm{v})$. Pentamidine was obtained commercially as a dry powder (Pentacarinat 300; Rhône-Poulenc) and was dissolved in pyrogen-free saline $(0.9 \% \mathrm{w} / \mathrm{v})$. Doses were adjusted weekly according to changes in body weight. Unless otherwise indicated, mice were treated with trimethoprim/sulphamethoxazole (po by gavage) twice per day (q $12 \mathrm{~h}$ ), 5 days per week for a total of 30 doses, or with pentamidine (sc) three times per week (Monday, Wednesday, Friday) for a total of nine doses. Treatment groups consisted of five to ten mice per group as indicated in the figure legends.

\section{Assay of trimethoprim and sulphamethoxazole}

Concentrations of trimethoprim, sulphamethoxazole and $\mathrm{N}$-acetyl sulphamethoxazole were determined by reversed phase HPLC (Blaser et al., 1993). Briefly, protein was removed from serum samples by adding a five-fold volume of $0.33 \mathrm{M}$ perchloric acid and subsequent centrifugation. Lung lavage fluids were collected by lavaging the lungs of killed mice three times with $1 \mathrm{~mL}$ of phosphate buffer containing $1 \mathrm{U} / \mathrm{mL}$ heparin and measuring the volume obtained. Protein was not removed from lung lavage fluids before HPLC analyses. Trimethoprim, sulphamethoxazole and $N$-acetyl sulphamethoxazole were separated using a Nova-Pak $\mathrm{C}_{18}$ column (Waters) eluted with a mixture of $85 \%(\mathrm{v} / \mathrm{v})$ phosphate buffer $(0.01 \mathrm{M}, \mathrm{pH} 3.0)$ and $15 \%(\mathrm{v} / \mathrm{v})$ acetonitrile at a flow rate of $1.6 \mathrm{~mL} / \mathrm{min}$, detected by a photodiode array detector, and concentrations corrected by external standardisation. The limits of detection of trimethoprim and sulphamethoxazole or $N$-acetyl sulphamethoxazole were 0.5 and $1.0 \mathrm{mg} / \mathrm{L}$ for serum specimens and 0.1 and $0.2 \mathrm{mg} / \mathrm{L}$ for lung lavage fluids, respectively. Coefficients of variation for $8-12$ repeated assays per analyte, specimen type and concentration ranged from $1 \cdot 3$ to $5 \cdot 2 \%$.

\section{Histological evaluations}

After bleeding from the vena cava, lungs were excised and fixed by immersion in $4 \%$ neutral phosphate-buffered formalin. Tissues were trimmed, embedded in Paraplast (Zahner Electronic AG, Kalbrunn, Switzerland) and $4 \mu \mathrm{m}$ longitudinal sections were stained either with haematoxylin and eosin (for general pathology) or Periodic Acid-Schiff's reagent (PAS; for $P$. carinii cyst walls and foamy material in alveoli) or Grocott's Methenamine Silver stain (for $P$. carinii cyst walls) (Luna, 1992). Three sections per lung were examined.

\section{Statistical evaluations}

Data presented are means \pm S.E.M. Statistical evaluation of the data (ANOVA [Fisher's PLSD], paired $t$-test, Spearman's Rank Correlation Coefficient $\left(r_{s}\right)$ used a commercial program (Statview II, Abacus Concepts, Berkley, California). When cysts counts were below the limit of detection, values for those samples were placed at the limit of detection 
(that is, one cyst/lung). However, this imposes possible underestimates of the levels of statistical significance.

\section{Results}

\section{Validation of cyst enumeration method}

Initial studies of Diff-Quik-stained scid mouse lung homogenates revealed stained bodies with morphologies and sizes comparable to previously published observations describing $P$. carinii in rat and human samples (see Masur et al., 1989; Davey \& Masur, 1990; Bartlett \& Smith, 1991; Smulian \& Walzer, 1992). That the scid mice bred by us were indeed positive for $P$. carinii was confirmed by the demonstration that bodies of the size and morphology of $P$. carinii were present in Giemsa-stained histological lung sections (not presented). Furthermore, as presented below, animals treated with trimethoprim/sulphamethoxazole, an agent known to be effective against $P$. carinii (see Masur et al., 1989; Davey \& Masur, 1990; Bartlett \& Smith, 1991; Smulian \& Walzer, 1992), did not contain such bodies.

Although devoid of punctate intra-cyst forms, the methylene blue method stained bodies of similar size and morphology to the Diff-Quik and Toluidine blue methods. When individual lung samples were serially diluted, all staining methods yielded a linear response of cyst count over a ten-fold range (data not presented). The cyst counts between the different methods correlated strongly (methylene blue and Toluidine blue, $r_{\mathbf{s}}=0.952$, $P=0.01$; methylene blue and Diff-Quik, $\left.r_{1}=0.976, P=0.01\right)$. Furthermore, determination of the cyst count in the lungs of 13 mice (range approximately $\log 4 \cdot 5-6.8$ cysts/g lung) demonstrated a good correlation between the methylene blue and Diff-Quik ( $r_{3}=0.937, P=0.0012$ ) staining methods (data not presented). However, the methylene blue staining consistently provided higher cyst counts than the Diff-Quik method. As the methylene blue method appeared to stain remaining lung tissue less avidly, this observation is likely due to the detection of cysts that would have been obscured by lung tissue staining strongly by the Diff-Quik method. For the methylene blue method, the range of cyst counts between individuals was on average $23 \%$ of the mean; the coefficient of variation was $12 \%$. The methylene blue stain was used for all of the experiments reported below.

\section{Progression of $\mathrm{P}$. carinii infection in scid mice}

Based upon previous information (Custer, Bosma \& Bosma, 1985; Roths et al., 1990), the body weights, lung weights, pulmonary $P$. carinii cyst counts and circulating white blood cell (WBC) and red blood cell (RBC) levels were measured in scid mice of different ages (Table I). As scid mice age, the levels of lung $P$. carinii cysts increase; that the cysts/g lung apparently decrease after 91 days of age may reflect the extensive increase in lung weight. This increase in $P$. carinii was correlated to increased lung weights, increased circulating WBC levels and to the slight increase in RBC levels, and in mice over 90 days of age, reduced body weights (for all $r_{s}, P<0.001$ ). Based upon this information, these indices, which are apparently associated with the progression of $P$. carinii infection, were chosen as additional indices to monitor the efficacy of therapy when administered to mice of approximately 90 days of age. Previous experiments established 
the uniformity of pulmonary cyst counts in 90 days old scid mice in that all mice were infected with similar $P$. carinii cyst counts (not presented).

Effect of trimethoprim/sulphamethoxazole treatment on $\mathrm{P}$. carinii infection in scid mice Scid mice were administered trimethoprim/sulphamethoxazole in order to determine if this agent, known to be efficacious in clinical and experimental studies, would demonstrate any dose-dependent reduction in pulmonary $P$. carinii cysts or alleviation of symptoms of infection. Scid mice ( $n=10$ per group) were treated with trimethoprim/ sulphamethoxazole administered twice daily, po for 30 applications over a 21 day period (ten treatments per week) at doses of 100/500, 50/250, 25/125, 10/50 and $0 / 0 \mathrm{mg} / \mathrm{kg} /$ day trimethoprim/sulphamethoxazole. One day after the last treatment the mice were killed and the body weights (Figure 1(a)), pulmonary cyst counts (Figure 1(b)), lung weights (Figure 1(c)) and blood WBC levels (Figure 1(d)) were determined.

At the end of treatment, all trimethoprim/sulphamethoxazole-treated mice had significantly increased body weight compared with saline-treated mice (Figure 1(a); $P<0.01)$ whose body weight had remained unchanged during the course of treatment (before treatment: $22.6 \pm 0.9 \mathrm{~g}$, after saline treatment: $22.1 \pm 0.5 ; P=0.6$, paired $t$-test). However, there were no significant differences in the weight of mice treated with different trimethoprim/sulphamethoxazole dosages (ANOVA, $P>0.05$ ). A dose-dependent reduction in pulmonary cysts was observed (Figure 1(b)) and ANOVA analysis demonstrated significant differences $(P<0.01)$ between the effectiveness of various doses to reduce the lung cyst count, with $100 / 500 \mathrm{mg} / \mathrm{kg} /$ day being most effective at reducing pulmonary cyst burden ( $\log 4.3 \pm 0.02 \mathrm{cysts} / \mathrm{g}$ lung $v s \log 6.9 \pm 0.09 \mathrm{cysts} / \mathrm{g}$ lung for saline treated, infected controls). Note that although $10 / 50 \mathrm{mg} / \mathrm{kg} / \mathrm{d}$ trimethoprim/sulphamethoxazole treatment reduced cyst levels compared with infected controls, the difference did not quite reach statistical significance compared with saline-treated infected controls $(P=0.06)$.

All doses of trimethoprim/sulphamethoxazole were effective in reducing lungs weights below that of saline-treated, infected, control mice $(0.48 \pm 0.02 \mathrm{~g})$, without demonstrating a linear dose-dependency (Figure 1(c)). All trimethoprim/sulphamethoxazole doses also reduced the circulating WBC levels (Figure 1(d)) compared with the level of control mice (WBC $11.02 \pm 0.41 \times 10^{9} \mathrm{~L}$ blood), with the two lower doses $(25 / 125$ and

Table I. Progression of $P$. carinii infection in scid mice

\begin{tabular}{cccccr}
\hline $\begin{array}{c}\text { Days of } \\
\text { age }\end{array}$ & $\begin{array}{c}\text { Body weight } \\
(\mathrm{g})\end{array}$ & $\begin{array}{c}\text { Lung weight } \\
(\mathrm{g})\end{array}$ & Log (cysts/g lung) & $\begin{array}{c}\text { WBC/L blood } \\
\left(\times 10^{9}\right)\end{array}$ & $\begin{array}{c}\text { RBC/L blood } \\
\left(\times 10^{13}\right)\end{array}$ \\
\hline $\begin{array}{r}P . \text { carinii infected } \\
35\end{array}$ & $21 \pm 1$ & $0.130 \pm 0.004$ & $5.38 \pm 0.06$ & $2.060 \pm 0.151$ & $0.82 \pm 0.04$ \\
63 & $24 \pm 1$ & $0.153 \pm 0.005$ & $6.6 \pm 0.1$ & $5.790 \pm 0.689$ & $0.9 \pm 0.02$ \\
91 & $23 \pm 1$ & $0.36 \pm 0.03$ & $7.31 \pm 0.05$ & $4.530 \pm 0.416$ & $1.02 \pm 0.03$ \\
125 & $20 \pm 2$ & $0.47 \pm 0.02$ & $6.9 \pm 0.1$ & $6.033 \pm 0.592$ & $1.10 \pm 0.04$ \\
$\begin{array}{c}\text { Uninfected } \\
92\end{array}$ & $26 \pm 2$ & $0.159 \pm 0.014$ & $<4.5$ & $2.100 \pm 0.400$ & $0.93 \pm 0.04$ \\
\hline
\end{tabular}

- Male scid mice ( $n=10$ /age) were killed at the indicated ages and their body and lung weights, lung $P$. carinii cyst load, and circulating leucocytes (WBC) and erythrocytes (RBC) determined. Values are means \pm S.E.M. 

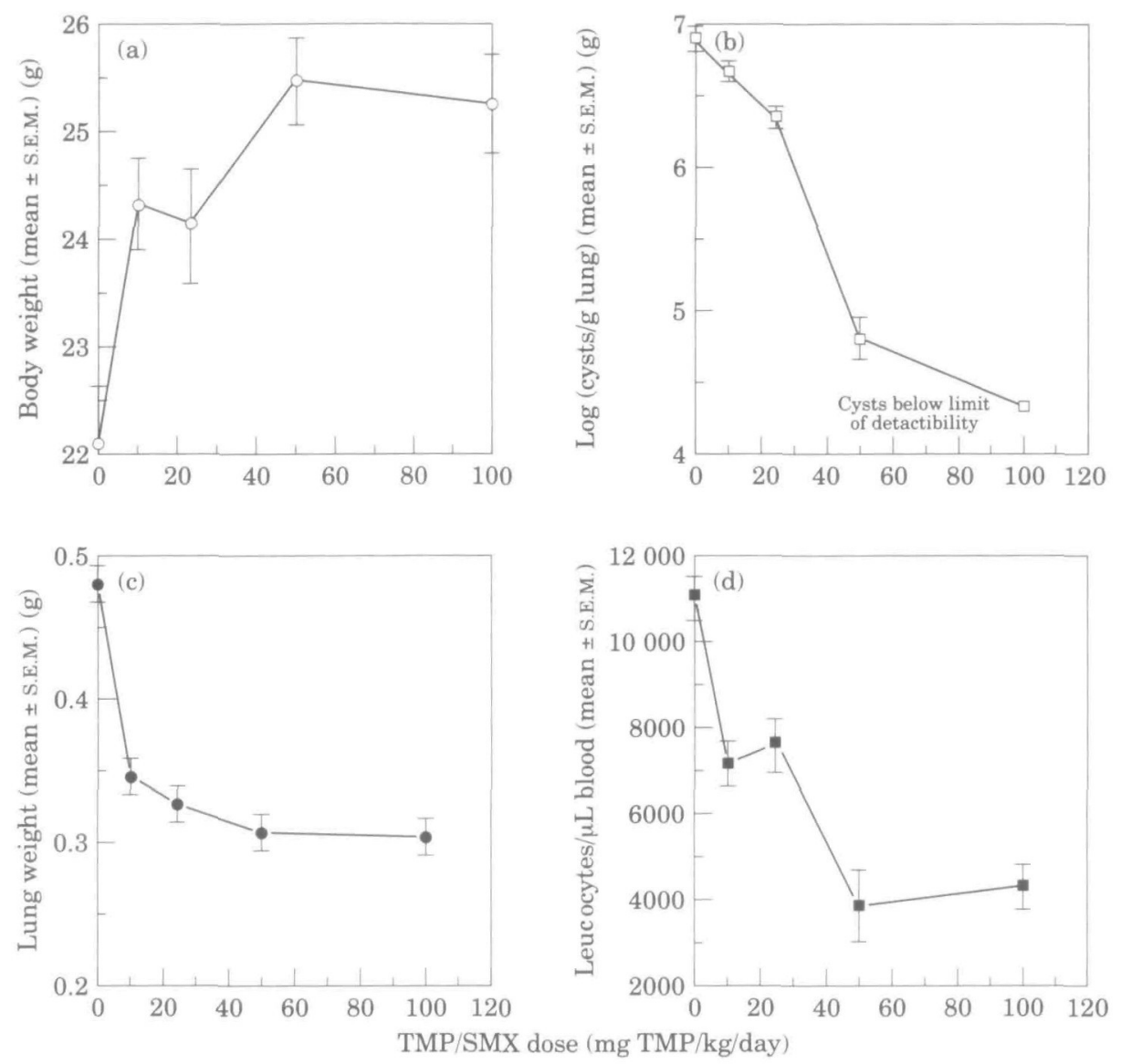

Figure 1. Trumethoprim/sulphamethoxazole (TMP/SMX) treatment of scid mice infected with $P$. carinii. scid mice of 91 days of age ( $n$ a 10/group) were treated po, bd, 5 days per week, with various doses of trimethoprim/sulphamethoxazole $(0 / 0,10 / 50,25 / 125,50 / 250$ or $100 / 500 \mathrm{mg} / \mathrm{kg} / \mathrm{day})$ for a total of 30 doses. One day after treatment, mice were killed and body weights (a), lung cyst $P$. carinii burden (b), lung weights (c) and circulating leucocytes (d) were determined. Symbols represent mean values \pm S.E.M.

$10 / 50 \mathrm{mg} / \mathrm{kg} / \mathrm{d}$ doses) resulting in a similar decrease $(P>0.05$; ANOVA) and the two higher doses $(100 / 500$ and $50 / 250 \mathrm{mg} / \mathrm{kg} /$ day $)$ being indistinguishable $(P>0.05$ : ANOVA), but reducing the WBC levels further than the lower doses (ANOVA $P<0.01$ vs $10 / 50$ or $25 / 125 \mathrm{mg} / \mathrm{kg} /$ day). Only the two highest doses of trimethoprim/ sulphamethoxazole significantly $(P<0.01$ ANOVA) reduced blood RBC levels compared with saline-treated infected controls (not shown): $100 / 500 \mathrm{mg} / \mathrm{kg} / \mathrm{d}$, $1.04 \pm 0.02 \times 10^{13} \mathrm{RBC} / \mathrm{L} ; 50 / 250 \mathrm{mg} / \mathrm{kg} /$ day, $1.03 \pm 0.03 \times 10^{13} \mathrm{RBC} / \mathrm{L} ;$ saline treated, infected controls, $1.2 \pm 0.03 \times 10^{13} \mathrm{RBC} / \mathrm{L}$. However, when considering calculated haematocrit values, there were no significant differences between groups (not presented) These results indicate that although the reduction in numbers of $P$. carinii in the lungs of scid mice is apparently linearly dependent upon the dose of trimethoprim/ sulphamethoxazole, the other indicators of progress (or resolution) of $P$. carinii infections may not always respond in a linear, dose-dependent manner. 


\section{Histological evaluation of the effect of trimethoprim/sulphamethoxazole treatment}

Infected, untreated control mice showed a moderate to marked pneumonia caused by $P$. carinii. The alveoli were filled with a foamy mass consisting of coalesced macrophages and $P$. carinii organisms (positive staining with PAS). $P$. carinii cysts could also be demonstrated with Grocott's methenamine silver stain (not shown). Infiltration with polymorphonuclear neutrophil granulocytes, lymphocytes and macrophages as well as hypertrophy of the alveolar epithelium were present. Although all lung lobes were affected, the distribution throughout the individual lobes was patchy, but there was little difference in the severity of pathology between the lobes. Treatment with different doses of trimethoprim/sulphamethoxazole reduced the severity of pneumonia in an apparently dose-dependent manner (Table II). The amount of PAS-staining material (indicative of the presence of $P$. carinii; Luna, 1992) was successively reduced at each trimethoprim/ sulphamethoxazole dose (Figure 2), which is in congruence with the quantitative data of cyst counts (Figure 1(b)). Furthermore, trimethoprim/sulphamethoxazole treatment was also associated with a reduction of inflammatory changes that was also apparently related to the dose used. At higher

Table II. Histological evaluation of the effect of trimethoprim/sulphamethoxazole. Treatment of $P$. carinii infected scid mice

\begin{tabular}{|c|c|c|c|}
\hline $\begin{array}{l}\text { TMP/SMX dose } \\
\text { (mg/kg/day, po) }\end{array}$ & $\begin{array}{l}\text { Animal } \\
\text { number }\end{array}$ & $\begin{array}{l}\text { Severity of } \\
\text { infection }\end{array}$ & Distribution \\
\hline $100 / 500$ & $\begin{array}{l}1 \\
2 \\
3\end{array}$ & $\begin{array}{l}\text { minimal } \\
\text { minimal-marked } \\
\text { minimal-slight }\end{array}$ & $\begin{array}{c}\text { patchy } \\
\text { patchy-diffuse, severity differs between lobes } \\
\text { patchy }\end{array}$ \\
\hline $50 / 250$ & $\begin{array}{l}1 \\
2 \\
3 \\
4\end{array}$ & $\begin{array}{l}\text { slight-moderate } \\
\text { minimal-slight } \\
\text { slight-moderate } \\
\text { slight-moderate }\end{array}$ & $\begin{array}{c}\text { patchy, severity differs between lobes } \\
\text { patchy } \\
\text { patchy-diffuse, severity differs between lobes } \\
\text { patchy, severity differs between lobes }\end{array}$ \\
\hline $25 / 125$ & $\begin{array}{l}1 \\
2 \\
3 \\
4\end{array}$ & $\begin{array}{l}\text { slight-moderate } \\
\text { marked } \\
\text { moderate } \\
\text { slight-moderate }\end{array}$ & $\begin{array}{c}\text { patchy, severity differs between lobes } \\
\text { diffuse } \\
\text { patchy } \\
\text { patchy, severity differs between lobes }\end{array}$ \\
\hline $10 / 50$ & $\begin{array}{l}1 \\
2 \\
3 \\
4\end{array}$ & $\begin{array}{l}\text { moderate } \\
\text { moderate } \\
\text { moderate } \\
\text { slight-moderate }\end{array}$ & $\begin{array}{c}\text { patchy } \\
\text { patchy to diffuse } \\
\text { patchy } \\
\text { patchy, severity differs between lobes }\end{array}$ \\
\hline $0 / 0$ & $\begin{array}{l}1 \\
2 \\
3 \\
4\end{array}$ & $\begin{array}{l}\text { moderate } \\
\text { moderate } \\
\text { moderate } \\
\text { marked }\end{array}$ & $\begin{array}{l}\text { patchy } \\
\text { patchy } \\
\text { patchy } \\
\text { diffuse }\end{array}$ \\
\hline
\end{tabular}

scid mice, 90 days of age, were treated with trimethoprim/sulphamethoxazole (TMP/SMX), bd, po, 5 days per week, for a total of 30 doses. One day after the end of treatment, the lungs were removed and processed for histological examination as described in Materials and methods.

Grading: minimal, $<25 \%$ of the alveolar area affected (cysts, macrophages, inflammatory cells/fibrin); slight, $25-50 \%$ of the alveolar affected; moderate, $50-75 \%$ of alveolar area affected; marked, $>75 \%$ of alveolar area affected.

'Distribution: Patchy, irregular distribution of cysts, mainly concentrated adjacent to bronchi or in subpleural regions; diffuse, regular distribution throughout lobe.

Marked accumulation of alveolar macrophages and intact cysts not clearly distinguishable from disintegrating cysts. 

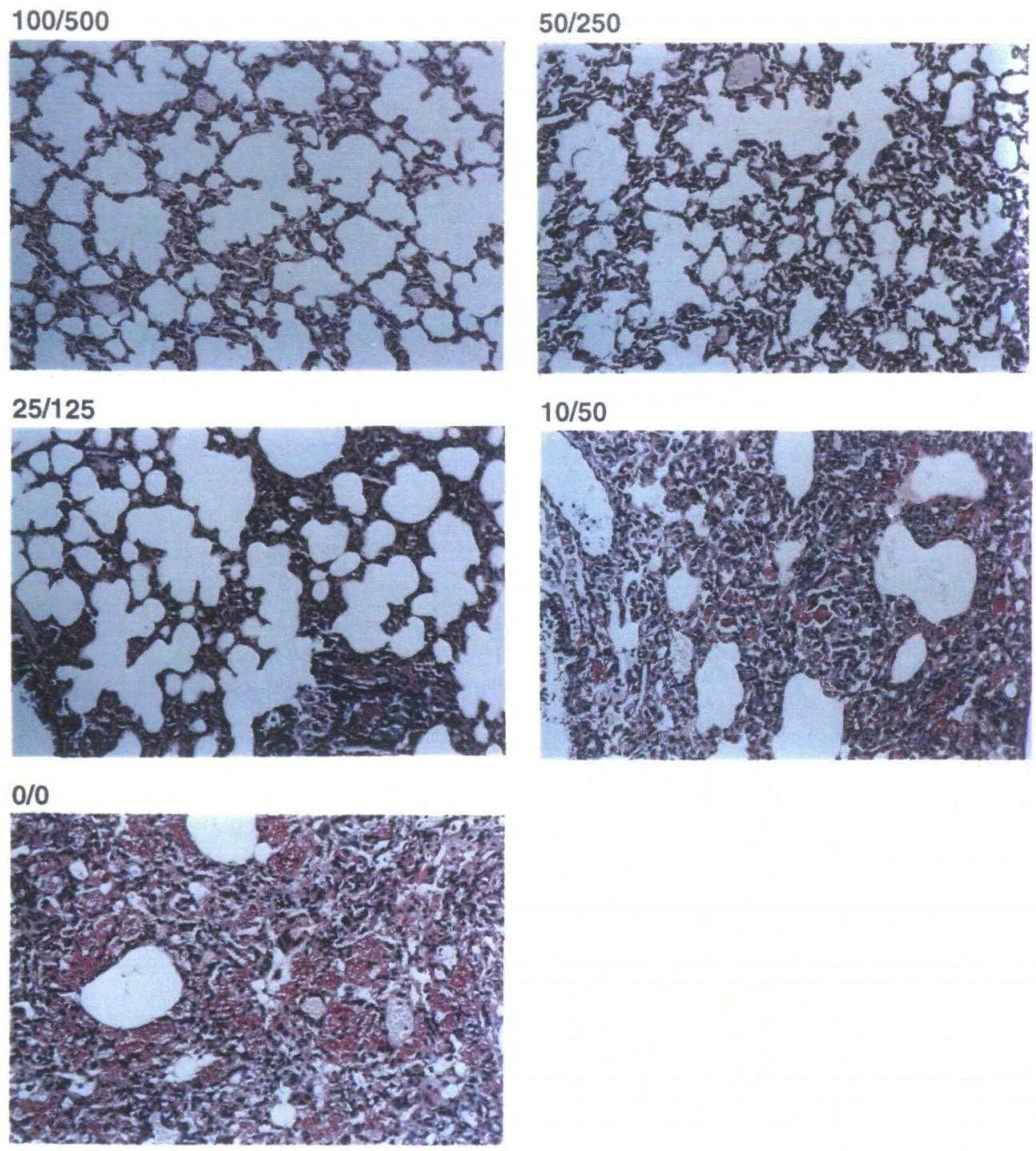

Figure 2. Histological evaluation of the lungs of scid mice treated with various doses of trimethoprim/sulphamethoxazole. $P$. carinii infected scid mice 90 days of age $(n=5 / g r o u p)$ were treated po, bd, 5 days per week, with various doses of trimethoprim/sulphamethoxazole $(0 / 0,10 / 50,25 / 125,50 / 250$ or $100 / 500 \mathrm{mg} / \mathrm{kg} /$ day) for a total of 30 doses. One day following the end of treatment, mice were killed and the lungs excised and immersed in $4 \%$ neutral phosphate buffered formalin, sectioned, and stained with PAS. Samples with representative histological features are presented.

doses, lung architecture was almost completely restored (Figure 2). Similar histological pictures of dose-dependent reduction in $P$. carinii numbers, and lung pathology, were observed from lung sections stained by haematoxylin and eosin or Grocott's methenamine silver stain (not shown). 
Correlation of anti-P. carinii activity with trimethoprim/sulphamethoxazole levels in body fuids

Measurement of the concentrations of trimethoprim, sulphamethoxazole and $N$-acetyl sulphamethoxazole within body fluids was performed by HPLC. After administering 9 treatments of trimethoprim/sulphamethoxazole $(0 / 0,10 / 50,25 / 125,50 / 250$ and $100 / 500 \mathrm{mg} / \mathrm{kg} / \mathrm{d}$, bd; $n=8$ per group) to scid mice, blood and lung lavage fluids were obtained after killing the mice $1 \mathrm{~h}$ after the last treatment. As shown in Figure 3(a), although the serum level of $N$-acetyl sulphamethoxazole was apparently linear with respect to trimethoprim/sulphamethoxazole dose, the concentration of sulphamethoxa-
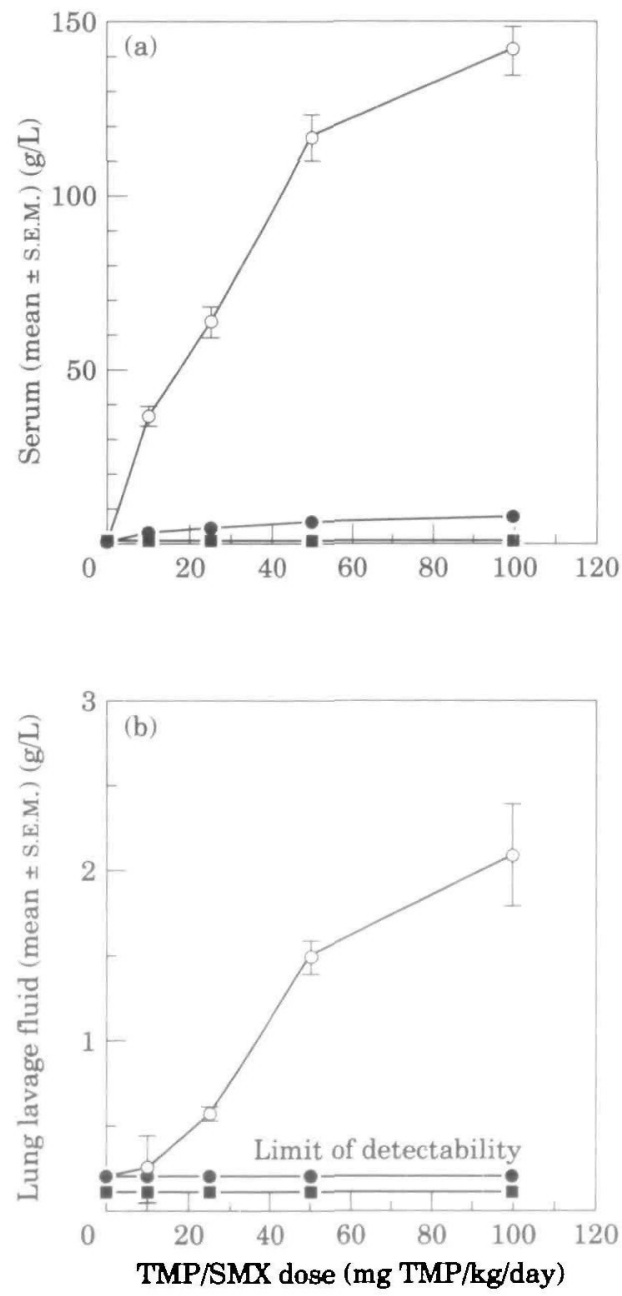

Figure 3. Effect of dose on the body fluid levels of trimethoprim, sulphamethoxazole and $N$-acetyl sulphamethoxazole in scid mice. $P$. carinil infected scid mice $(n=8 /$ group) were administered 9 treatments of trimethoprim/sulphamethoxazole $(0 / 0,10 / 50,25 / 125,50 / 250$ or $100 / 500 \mathrm{mg} / \mathrm{kg} / \mathrm{day})$, and serum and lung lavage fluid were obtained one hour after the last treatment. The levels of trimethoprim, sulphamethoxazole and $N$-acetyl sulphamethoxazole within serum (a) and lung lavage fluid (b) were determined by HPLC. Symbols represent mean values \pm S.E.M. and symbols within stippled areas represent samples below the limit of detectability. Numbers indicate the daily dose of trimethoprim/sulphamethoxazole in $\mathrm{mg} / \mathrm{kg}$. All photographs $\times 200$. $O$, Sulphamethoxazole; $\bullet, N$-sulphamethoxazole; $\mathbf{\square}$, trimethoprim. 


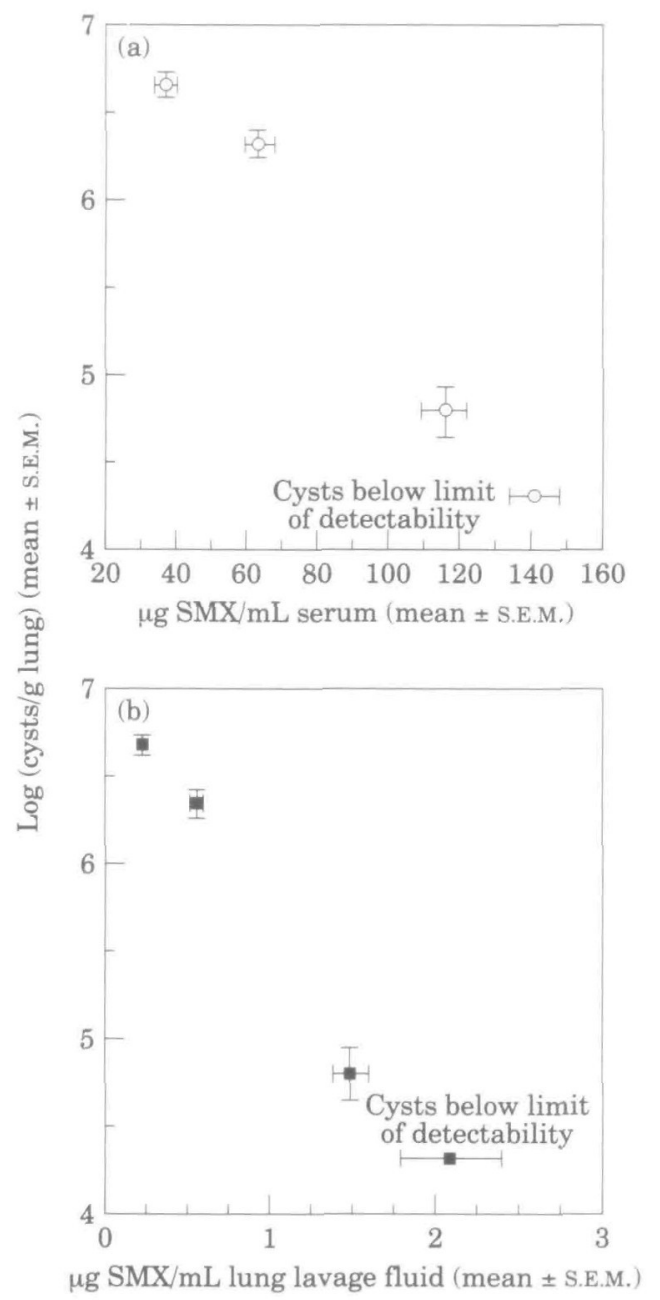

Figure 4. Comparison of body fluid sulphamethoxazole levels and final lung cyst levels. The concentrations of sulphamethoxazole were obtained from $P$. carinii infected scid mice $(n=8 /$ group) receiving 9 trimethoprim/sulphamethoxazole treatments as described in Figure 2, and the lung cyst counts were determined from mice ( $n=10$ /group) receiving 30 trimethoprim/sulphamethoxazole treatments as described in Figure 1. Symbols represent mean values \pm S.E.M. derived from experiments run in parallel. Panel A compares serum sulphamethoxazole levels with final cyst counts and panel B compares cyst counts with lung lavage fluid sulphamethoxazole concentration.

zole was not, although the sulphamethoxazole concentrations were all significantly different from each other (ANOVA; $P<0.01$ ). Surprisingly, at $1 \mathrm{~h}$ post administration, trimethoprim was undetectable $(<0.5 \mathrm{mg} / \mathrm{L})$. A non-linear response of lung lavage fluid sulphamethoxazole concentration to dose was also observed (Figure 3(b)); neither trimethoprim ( $<0.5 \mathrm{mg} / \mathrm{L}$ ) nor $N$-acetyl sulphamethoxazole $(<0.2 \mathrm{mg} / \mathrm{L})$ was detected. Maximal sulphamethoxazole penetration into lung lavage fluid (1.3\% of serum levels) occurred with $50 / 250 \mathrm{mg} / \mathrm{kg} /$ day trimethoprim/sulphamethoxazole, with no greater per cent penetration occurring with the higher dose (not shown).

Comparison of body fluid antimicrobial concentrations with cyst counts obtained from experiments run in parallel suggest correlations between serum (Figure 4(a)) and lung 
lavage fluid (Figure 4(b)) sulphamethoxazole concentrations and the levels of pulmonary $P$. carinii present after 30 administrations of various doses of trimethoprim/ sulphamethoxazole.

Progression of $\mathrm{P}$. carinii infection during trimethoprim/sulphamethoxazole treatment

Groups of scid mice $(n=5)$ were treated with $100 / 500 \mathrm{mg} / \mathrm{kg} / \mathrm{d}$ trimethoprim/ sulphamethoxazole or saline (po, bd, 5 days per week) and killed sequentially to determine the time course of resolution of $P$. carinii infection. As shown in Figure 5, although the cyst count tended to be reduced after one week of treatment (trimethoprim/sulphamethoxazole treated, $6 \cdot 71 \pm 0.28$; saline treated, infected controls, $7 \cdot 16 \pm 0.21 \log$ cysts/g lung; $P>0 \cdot 05, t$-test), a statistically significant reduction in cysts did not occur until the end of two weeks of treatment. This was followed by a dramatic decline in lung $P$. carinii load (below the limit of detection) at end of three weeks of treatment (trimethoprim/sulphamethoxazole treated, 3.97 \pm 0.05 ; saline treated, infected controls, $7 \cdot 15 \pm 0.1 \mathrm{log}$ cysts/g lung; $P<0.01, t$-test). Similarly, reduction in lung weight in response to trimethoprim/sulphamethoxazole treatment was delayed until the end of two weeks of treatment (pre-treatment, $0.4 \pm 0.04 \mathrm{~g}$; week one, trimethoprim/sulphamethoxazole $0.40 \pm 0.2 \mathrm{~g}$, saline treated, infected controls, $0.42 \pm 0.03 \mathrm{~g}$; week two, trimethoprim/sulphamethoxazole $0.32 \pm 0.2 \mathrm{~g}$, saline treated, infected controls, $0.46 \pm 0.03 \mathrm{~g}$ ) and continued until the end of the treatment schedule (trimethoprim/sulphamethoxazole treated, $0.25 \pm 0.003 \mathrm{~g}$ lung; saline treated, infected controls, $0.41 \pm 0.02 \mathrm{~g}$ lung; $P<0.01, t$-test). Circulating WBC levels tended to decline after one week of trimethoprim/sulphamethoxazole treatment (pre-treatment, leucocytes $7.4 \pm 1.861 \times 10^{9} \mathrm{~L}$; week one, leucocytes $4.4 \pm 1.153 \times 10^{9} \mathrm{~L}$, saline treated, infected controls, $6.640 \pm 1.541 \times 10^{9} \mathrm{~L}$ ), but only became significantly different from saline treated, infected controls at the end of two weeks of treatment (trimethoprim/ sulphamethoxazole treated $2.4 \pm 0.256 \times 10^{9} \mathrm{~L}$, saline treated, infected controls

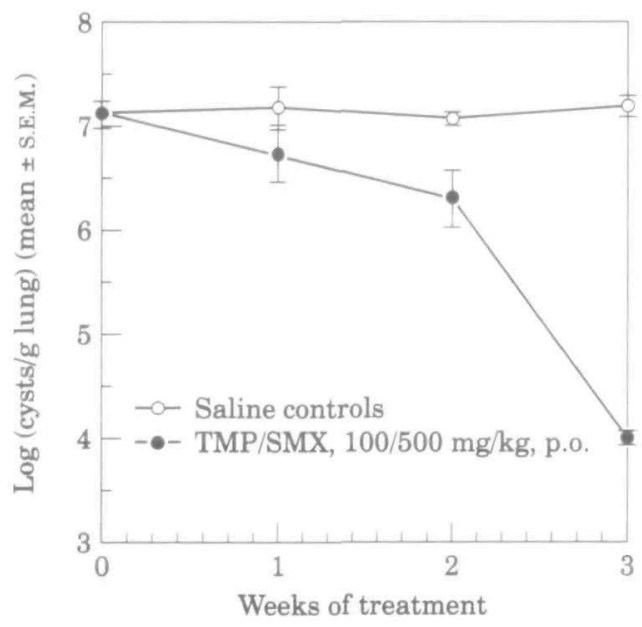

Flgure 5. Progression of $P$. carinii infection in scid mice during treatment with trimethoprim/sulphamethoxazole. $P$. carinii infected scid mice $(n=5 / \mathrm{group}$ ) were treated with either $100 / 500 \mathrm{mg} / \mathrm{kg} /$ day trimethoprim/sulphamethoxazole ( 0 ; bd, po, 5 days per week) or saline $(O)$ and killed after 1,2 or 3 weeks $(10,20$ or 30 treatments respectively). Symbols represent mean values of log cysts/g lung \pm S.E.M. 


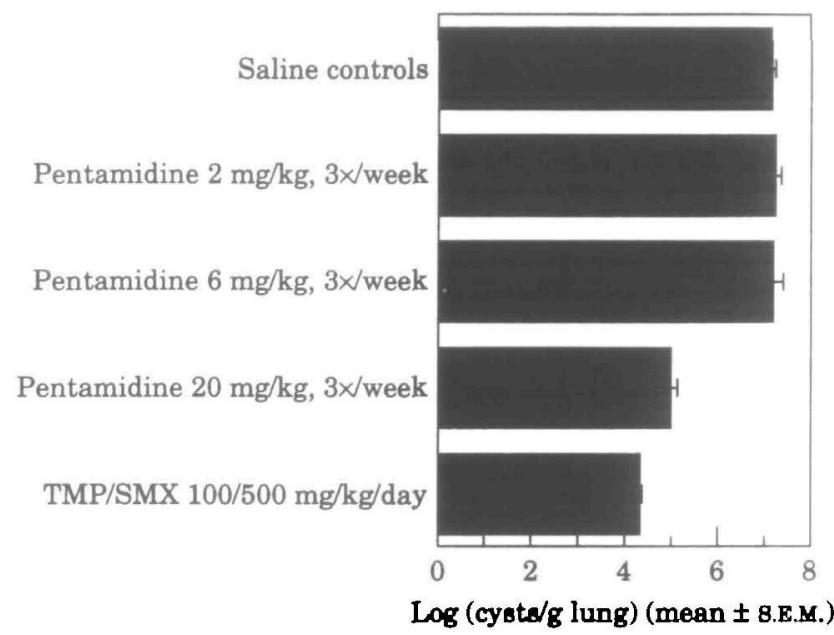

Figure 6. Pentamidine treatment of scid mice infected with $P$. carinii scid mice ( $n=7 /$ group) were treated with $100 / 500$ trimethoprim/sulphamethoxazole (bd, po, 5 days per week), pentamidine $(20,6$, or $2 \mathrm{mg} / \mathrm{kg}, s c$, three times per week), or saline (po) for 21 days of treatment. One day after the last treatment, mice were killed and the lung cyst counts were determined.

$8.46 \pm 1.236 \times 10^{9} \mathrm{~L}$ blood; $P<0.01 ; t$-test). No further changes in WBC levels occurred after an additional week of treatment.

\section{Effect of trimethoprim/sulphamethoxazole treatment on scid mice free of $\mathrm{P}$. carinii}

In order to determine if changes in body weight, lung weight and circulating blood cells following trimethoprim/sulphamethoxazole treatment were indeed due to reduction of pulmonary $P$. carinii, scid mice of 90 days of age obtained from a colony free of histologically-detectable $P$. carinii were treated either saline $(n=10)$ or $100 / 500 \mathrm{mg} / \mathrm{kg} / \mathrm{d}$ trimethoprim/sulphamethoxazole $(n=10)$ as described above. At the end of treatment, there were no significant differences $(P>0.05 ; t$-test $)$ between the two groups with respect to body weights (trimethoprim/sulphamethoxazole, $27.5 \pm 0.5 \mathrm{~g}$; controls, $26.5 \pm 0.5$ ), lung weights (trimethoprim/sulphamethoxazole $0.157 \pm 0.004 \mathrm{~g}$; controls, $0.159 \pm 0.004$ ), blood erythrocyte levels (trimethoprim/sulphamethoxazole $9.9 \times 10^{12} \mathrm{~L}$; controls, $9.3 \times 10^{12} \mathrm{~L}$ ) or blood leucocyte levels (trimethoprim/sulphamethoxazole, $2.5 \pm 0.34 \times 10^{9} \mathrm{~L}$; controls, $2.05 \pm 0.14 \times 10^{9} \mathrm{~L}$ ). $P$. carinii cysts were below the limit of detectability in all of these mice at the end of treatment.

\section{Effect of pentamidine dose on $\mathrm{P}$. carinii infection in scid mice}

Pentamidine is another recommended drug for treatment and prophylaxis of $P$. carinii infections, and therefore affords a second standard drug to evaluate the utility of scid mice as a therapeutic model. Scid mice $(n=7$ per group) were treated with trimethoprim/sulphamethoxazole $(100 / 500 \mathrm{mg} / \mathrm{kg} / \mathrm{day}$, po, bd for 5 days per week), or various doses of pentamidine $(20,6$ or $2 \mathrm{mg} / \mathrm{kg}$, sc, three times per week) for 21 days; this corresponds to 60,18 or $6 \mathrm{mg} / \mathrm{kg} /$ week. Macroscopic lesions at the site of pentamidine injection were not observed. Figure 6 indicates that trimethoprim/ sulphamethoxazole and $60 \mathrm{mg} / \mathrm{kg} /$ week pentamidine were both effective in reducing lung 
cyst counts $(100 / 500 \mathrm{mg} / \mathrm{kg} / \mathrm{d}$ trimethoprim/sulphamethoxazole superior to $60 \mathrm{mg} / \mathrm{kg} /$ week pentamidine, $P<0.01$; ANOVA), and the highest dose of pentamidine being superior to all other doses $(P<0.01$; ANOVA). Furthermore, all doses of pentamidine were effective in reducing lung weight $(60 \mathrm{mg} / \mathrm{kg} /$ week, $0.24 \pm 0.06 \mathrm{~g} ; 18 \mathrm{mg} / \mathrm{kg} /$ week, $0.32 \pm 0.04 \mathrm{~g} ; \quad 6 \mathrm{mg} / \mathrm{kg} /$ week $0.37 \pm 0.01 \mathrm{~g} ;$ saline treated, infected controls, $1.2 \pm 0.02 \mathrm{~g}$ ), and the highest dose of pentamidine was as effective as $100 / 500 \mathrm{mg} / \mathrm{kg} / \mathrm{d}$ trimethoprim/sulphamethoxazole $(0.27 \pm 0.06 \mathrm{~g} ; \quad P<0.01$ vs infected controls; ANOVA). ANOVA analysis also indicated the pentamidine-induced reduction in lung weight to be dose-dependent in that each dose was significantly different from each other $(P<0.01)$. All treatment regimens reduced the circulating WBC levels compared with infected controls $\left(60 \mathrm{mg} / \mathrm{kg} /\right.$ week, $3.216 \pm 0.419 \times 10^{9} \mathrm{~L} ; \quad 18 \mathrm{mg} / \mathrm{kg} /$ week, $4.128 \pm 0.658 \times 10^{9} \mathrm{~L} ; 6 \mathrm{mg} / \mathrm{kg} /$ week $4.883 \pm 0.499 \times 10^{9} \mathrm{~L}$; saline treated, infected controls, $9.242 \pm 1.083 \times 10^{9} \mathrm{~L}$ ), however, the dose-dependency of the response with pentamidine was statistically not significant. No dose of pentamidine was capable of significantly promoting weight gain nor reducing circulating RBC levels during the course of treatment (not presented).

\section{Discussion}

The development of a variety of in-vitro methodologies to evaluate anti-pneumocystis compounds (Pifer, Pifer \& Woods, 1983; Bartlett, Eichholtz \& Smith, 1985; Cushion et al., 1985; Bartlett et al., 1986, 1992; Broughton \& Queener, 1991; Comley et al., 1991; Queener et al., 1991) has not obviated the requirement of in-vivo testing of novel therapeutic strategies. Previous communications about $P$. carinii infections in cortisone-treated mice (Walzer et al., 1979b), nude mice (Ueda et al., 1977; Walzer et al., 1977), CD4 ${ }^{+}$T-cell-depleted mice (Shellito et al., 1990) and scid mice (Walzer et al., 1979a; Sundberg et al., 1989; Roths et al., 1990; Shultz et al., 1990) have focused on the progression of pathology (Walzer et al., 1979a; Shultz et al., 1989). Earlier evidence suggested that these mice are responsive to treatment: although scid mice treated with trimethoprim/sulphamethoxazole in drinking water (100/500 trimethoprim/ sulphamethoxazole $\mathrm{mg} / \mathrm{kg} / \mathrm{d}$; Walzer et al., 1979a; Shultz et al., 1989) demonstrated increased survival times, treatment apparently did not eliminate $P$. carinii from the lungs (Shultz et al., 1989); however, no quantitative data have been presented so far. The present study presents the first rigorous evaluation of the potential of pneumocystis-infected scid mice as a model for the evaluation of novel agents.

The present study has confirmed several of the features of endogenous infection as documented by Roths et al. (1990): the severity of $P$. carinii infection, the uniformity of infection (100\% of mice positive for infection), elevated lung weight, and elevated circulating erythrocytes. Furthermore, recent evidence has indicated that $P$. carinii bearing mice can transmit this infection to scid mice free of pneumocystis; recipient mice apparently uniformly develop a pulmonary infection (Powles et al., 1992). Lastly, scid mice free of endogenous $P$. carinii possible could be infected with isolates obtained from patients (Sethi, 1992), although recent evidence suggests that $P$. carinii has a restricted host range (Gigliotti et al., 1993). This evidence indicates that the use of scid mice permits the establishment of a reliable model of $P$. carinii pulmonary infections.

Twice per day treatment of scid mice with trimethoprim/sulphamethoxazole resulted in a linear, dose-dependent reduction of pulmonary $P$. carinii, but changes in associated pathology were apparently not linearly dose-dependent; we have found that 
trimethoprim/sulphamethoxazole administered one per day also demonstrates similar reduction in cyst counts and associated pathology (not presented). Of interest was the significant increase in body weight, and reduced lung weight and blood WBC levels obtained with a poorly effective dose of trimethoprim/sulphamethoxazole $(10 / 50 \mathrm{mg} / \mathrm{kg} /$ d). Although this dose was associated with a slight improvement in lung histopathology, only slight reductions in PAS-staining material and $P$. carinii cysts were observed. Similar data were obtained after pentamidine administration, where only the $60 \mathrm{mg} / \mathrm{kg} /$ week dose was capable of reducing the numbers of $P$. carinii cysts, where as lower doses were able to reduce lung weights and circulating WBC levels. Although the reason(s) for this remain unclear, it may be that although low doses of trimethoprim/ sulphamethoxazole or pentamidine are unable to kill $P$. carinii, such doses may be sufficient to interfere with aspects of the metabolism of this organism which are associated with the induction of pathological changes. However, in comparison to in-vitro data, the serum $(36.7 \pm 2.5 \mathrm{mg} / \mathrm{L})$ or lung lavage fluid $(0.24 \pm 0.02 \mathrm{mg} / \mathrm{L})$ sulphamethoxazole concentrations attained one hour after a dose of $10 / 50 \mathrm{mg} / \mathrm{kg} /$ day trimethoprim/sulphamethoxazole would be insufficient to inhibit greatly the metabolism or reduce the viability of this microorganism (Pesanti, 1980; Comley et al., 1991; Martinez \& Kovacs, 1993). Nevertheless, this experimental study indicates potentially therapeutic activities of trimethoprim/sulphamethoxazole doses that result in serum levels $1 \mathrm{~h}$ post administration that are much lower than trough levels achieved clinically during standard high-dose treatment of $P$. carinii pneumonia (Blaser et al., 1993). This might suggest that lower doses of trimethoprim/sulphamethoxazole may be clinically efficacious and perhaps reduce the incidence of adverse reactions in AIDS patients treated with this antimicrobial combination (Lee \& Safrin, 1992).

Mice killed after treatment with $100 / 500 \mathrm{mg} / \mathrm{kg} /$ day trimethoprim/sulphamethoxazole at various time points demonstrated that neither the reduction in cysts nor resolution of symptoms of infection were significantly altered before two weeks of treatment (20 doses), indicating that treatment time is a critical facet of this model to evaluate anti-pneumocystis agents. This delay in the activity of trimethoprim/sulphamethoxazole has been reported previously, and a similar effect has been observed for pentamidine (Schmatz et al., 1992). As in-vitro (Pesanti, 1980; Pifer et al., 1983; Bartlett et al., 1985) evidence suggests that trimethoprim/sulphamethoxazole is either unable to kill $P$.carinii, or has only weak killing activity, the reduction of the cyst counts following administration to trimethoprim/sulphamethoxazole may require the participation of host defence systems. Several reports (Masur \& Jones, 1978; Pesanti, 1991; Hidalgo et al., 1992; Taylor, Phillips \& Easmon, 1992) have indicated the need for opsonins (antibody or, to a lesser extent, complement; Hidalgo et al., 1992), or activation of macrophages by interferon $\gamma$ (Pesanti, 1991), for efficient phagocytosis of $P$. carinii by macrophages or neutrophils. Although complement is likely to be unaffected, scid mice are unable to mount an antibody response to provide efficient opsonisation, and this apparently prevents the control of $P$. carinii infections (Roths et al., 1990). In light of these restraints of the host defence system, it may be that trimethoprim/sulphamethoxazole is indeed 'cidal in vivo or is able to alter the microorganism so that it is more readily phagocytosed, similar to the effect of antibiotics on bacteria (van den Broek, 1989).

Limited pharmacokinetic analysis suggested a correlation between the level of sulphamethoxazole in serum and lung lavage fluid one hour post administration of various doses of trimethoprim/sulphamethoxazole and reduction of lung $P$. carinii occurring after 30 administrations of those doses. Recent evidence (Walzer et al., 1992a) 
suggests that the anti-pneumocystis activity of this antimicrobial combination is largely due to sulphamethoxazole. Although body fluid levels of sulphamethoxazole (and $N$-acetyl sulphamethoxazole) were not linear with dose, the body fluid levels attained were significantly different between doses. Trimethoprim was not detected in serum or lung lavage fluid at one hour post administration of any dose of trimethoprim/ sulphamethoxazole. It is likely that this represents rapid elimination of this compound in mice as we have determined (unpublished) that in Balb/c mice, the genetic background of the scid mice used in the present study, trimethoprim has a $T_{1 / 2}$ of approximately $2 \mathrm{~h}$ in serum or lung lavage fluid following im or po administration of $100 / 500 \mathrm{mg} / \mathrm{kg} / \mathrm{day}$ trimethoprim/sulphamethoxazole, whereas sulphamethoxazole has a $T_{1 / 2}$ of about $20 \mathrm{~h}$ in serum and about $10 \mathrm{~h}$ in lung lavage fluid. Although the $T_{1 / 2}$ of sulphamethoxazole in Balb/c mice is similar to that in humans (8.6 h (Grose, Bodey \& Loo, 1979); $11 \mathrm{~h}$ (Kaplan et al., 1973); $14 \mathrm{~h}$ (Stevens et al., 1991)), the $T_{1 / 2}$ of trimethoprim in mice is considerably shorter than the $T_{1 / 2}$ of trimethoprim in humans ( $7.6 \mathrm{~h}$ (Grose et al., 1979); $11 \mathrm{~h}$ (Kaplan et al., 1973); $13.6 \mathrm{~h}$ (Stevens et al., 1991)). This confirms previous observations of rapid elimination of trimethoprim in rodents (Walzer et al., 1992a). A previous study (Walzer et al., 1992a), demonstrated apparent accumulation of trimethoprim without concurrent accumulation of sulphamethoxazole in dexamethasone-immunosuppressed rats. However, in the present study, no evidence of trimethoprim accumulation was apparent in scid mice, although our studies demonstrate dose-dependent increases in serum sulphamethoxazole levels $1 \mathrm{~h}$ post administration in scid mice.

Taken together, the data obtained in the present study using compounds with proven anti-pneumocystis activity has demonstrated that scid mice bearing endogenous $P$. carinii infection are amenable to chemotherapeutic intervention. Both trimethoprim/ sulphamethoxazole and pentamidine demonstrated dose-dependent reduction in pulmonary $P$. carinii cysts, and in the case of trimethoprim/sulphamethoxazole, this effect was correlated to the concentration of sulphamethoxazole in both serum and lung lavage fluid, but required at least two weeks of treatment before a significant reduction of $P$. carinii could be observed. However, resolution of a variety of indices of infection were not correlated, in a linear fashion, to antimicrobial dose or the reduction of cysts. This model of $P$. carinii pulmonary infection is likely to be useful for the evaluation of novel anti-pneumocystis compounds and, because of the treatment-dependent resolution of associated pathology, may also be useful for exploring novel treatment modalities.

\section{References}

Bartlett, M. S., Edlind, T. D., Durkin, M. M., Shaw, M. M. Queener, S. F. \& Smith J. W. (1992). Antimicrotubule benzimidazoles inhibit in vitro growth of Pneumocystis carinii. Antimicrobial Agents and Chemotherapy 36, 779-82.

Bartlett, M. S., Eichhlotz, R. \& Smith, J. W. (1985). Antimicrobial susceptibility of Pneumocystis carinii in culture. Diagnostic Microbiology and Infectious Disease 3, 381-7.

Bartlett, M. S., Fishman, J. A., Durkin, M. M., Queener, S. F. \& Smith, J. W. (1990). Pneumocystis carinit: improved models to study efficacy of drugs for treatment or prophylaxis of pneumocystis pneumonia in the rat (Rattus sp.). Experimental Parasitology 70, 100-6.

Bartlett, M. S., Marr, J. J., Queener, S. F., Klein, R. S. \& Smith, J. W. (1986). Activity of inosine analogs against Pneumocystic carinii in culture. Antimicrobial Agents and Chemotherapy 30, $181-3$.

Bartlett, M. S., Queener, S. F., Tidwell, R. R., Milhous, W. K., Berman, J. D., Ellis, W. Y. et al. (1991). 8-Aminoquinolones from Walter Reed Army Institute for Research for treatment 
and prophylaxis of pneumocystis pneumonia in rat models. Antimicrobial Agents and Chemotherapy 35, 277-82.

Bartlett, M. S. \& Smith, J. W. (1991). Pneumocystis carinii, an opportunist in immunocompromised patients. Clinical Microbiology Reviews 4, 137-49.

Blaser, J., Joos, B., Opravil, M. \& Lüthy, R. (1993). Variability of serum concentrations of trimethoprim and sulphamethoxazole during high dose therapy, Infection 21, 206-9.

Boylan, C. J. \& Current, W. L. (1992). Improved rat model of Pneumocystis carinii pneumonia: induced laboratory infections in pneumocystis-free animals. Infection and Immunity 60, 1589-97.

Bray, M. V., Barthold, S. W., Sidman, C. L., Roths, J. \& Smith, A. L. (1993). Exacerbation of Pneumocystis carinii pneumonia in immunodeficient (scid) mice by concurrent infection with a pneumovirus. Infection and Immunity 61, 1586-8.

Broughton, M. C. \& Queener, S. F. (1991). Pneumocystis carinii dihydrofolate reductase used to screen potential antipneumocystis drugs. Antimicrobial Agents and Chemotherapy 35, $1348-55$.

Brun-Pascaud, M., Fay, M., Zhong, M., Bauchet, J., Dux-Guyot, A. \& Pocidalo, J.-J. (1992). Use of fluoroquinolones for prophylaxis of murine Pneumocystis carinii pneumonia. Antimicrobial Agents and Chemotherapy 36, 470-2.

Chen, W., Gigliotti, F. \& Harmsen, A. G. (1993a). Latency is not an inevitable outcome of infection with Pneumocystis carinii. Infection and Immunity 61, 5406-9.

Chen W., Havell, E. A., Gigliotti, F. \& Harmsen, A. G. (1993b). Interleukin-6 production in a murine model of Pneumocystis carinii pneumonia: relation to resistance and inflammatory response. Infection and Immunity 61, 97-102.

Chen, W., Havell, E. A. \& Harmsen, A. G. (1992a). Importance of endogenous tumor necrosis factor alpha and gamma interferon in host resistance against Pneumocystis carinii infection. Infection and Immunity 60, 1279-84.

Chen, W., Havell, E. A., Moldawer, L. L., McIntyre, K. W., Chizzonite, R. A. \& Harmsen, A. G. (1992). Interleukin 1: an important mediator of host resistance against Pneumocystis carinii. Journal of Experimental Medicine 176, 713-8.

Chen, W., Mills, J. W. \& Harmsen, A. G. (1992b). Development and resolution of Pneumocystis carinii pneumonia in severe combined immunodeficient mice: a morphological study of host responses. International Journal of Experimental Pathology 73, 709-20.

Clarkson, A. B., Williams, D. E. \& Rosenberg, C. (1988). Efficacy of DL- $\alpha$-difluoromethylornithine in a rat model of Pneumocystis carinii pneumonia. Antimicrobial Agents and Chemotherapy 32, $1158-63$.

Comley, J. C. W., Mullin, R. J., Wolfe, L. A., Hanlon, M. H. \& Ferone, R. (1991). Microculture screening assay for primary in vitro evaluation of drugs against Pneumocystis carinii. Antimicrobial Agents and Chemotherapy 35, 1965-74.

Cushion, M. T., Stanforth, D., Linke, M. J. \& Walzer, P. D. (1985). Method of testing the susceptibility of Pneumocystis carinii to antimicrobial agents in vitro. Antimicrobial Agents and Chemotherapy 28, 796-801.

Custer, R. P., Bosma, G. C. \& Bosma, M. J. (1985). Severe combined immunodeficiency (SCID) in the mouse. Pathology, reconstitution, neoplasms. American Journal of Pathology 120, 464-77.

Davey, R. T. \& Masur, H. (1990). Recent advances in the diagnosis, treatment, and prevention of Pneumocystis carinii pneumonia. Antimicrobial Agents and Chemotherapy 34, 499-504.

Dembinski, A. S., Smith, D. M., Goldsmith, J. C. \& Woods, G. L. (1990). Widespread dissemination of Pneumocystis carinii infection in a patient with acquired immune deficiency syndrome receiving long-term treatment with aerosolised pentamidine. American Journal of Clinical Pathology 95, 96-100.

Gigliotti, F., Harmsen, A. G., Haidaris, C. G. \& Haidaris, P. J. (1993). Pneumocystis carinii is not universally transmissible between mammalian species. Infection and Immunity 61, 2886-90.

Grose, W. E., Bodey, G. P. \& Loo, T. L. (1979). Clinical pharmacology of intravenously administered trimethoprim-sulfamethoxazole. Antimicrobial Agents and Chemotherapy 15, 447-51.

Harmsen, A. G. \& Stankiewicz, M. (1990). Requirement for $\mathrm{CD4}^{+}$cells in resistance to Pneumocystis carinii pneumonia in mice. Journal of Experimental Medicine 172, 937-45. 
Hidalgo, H. A., Helmke, R. J., German, V. F. \& Mangos, J. A. (1992). Pneumocystis carinii induces an oxidative burst in alveolar macrophages. Infection and Immunity 60, 1-7.

Hughes, W. T., Gray, V. L., Gutteridge, W. E., Latter, V. W. \& Pudney, M. (1990). Efficacy of a hydroxynaphthoquinone, 556C80, in experimental Pneumocystic carinii pneumonitis. Antimicrobial Agents and Chemotherapy 34, 225-8.

Hughes, W. T., McNabb, P. C., Makres, T. D. \& Feldman, S. (1974). Efficacy of trimethoprim and sulfamethoxazole in the prevention and treatment of Pneumocystis carinii pneumonitis. Antimicrobial Agents and Chemotherapy 5, 289-93.

Hughes, W. T. \& Smith, B. L. (1984). Efficacy of diaminodiphenylsulfone and other drugs in murine Pneumocystis carinii pneumonitis. Antimicrobial Agents and Chemotherapy 26, 436-40.

Kaplan, S. A., Weinfeld, R. E., Abruzzo, C. W., McFaden, K., Jack, M. L. \& Weissman, L. (1973). Pharmacokinetic profile of trimethoprim-sulfamethoxazole in man. Journal of Infectious Diseases 128, S547-S55.

Kovacs, J. A., Allegra, C. J., Kennedy, S., Swan, J. C., Drake, J., Parrillo, J. E. et al. (1988). Efficacy of trimetrexate, a potent lipid-soluble antifolate, in the treatment of rodent Pneumocystis carinii pneumonia. American Journal of Tropical Medicine and Hygiene 39, 491-6.

Lee, B. L. \& Safrin, S. (1992). Drug interactions and toxicities in patients with AIDS. Current Opinion in Infectious Diseases 5, 231-40.

Luna, L. G. (1992). Histopathological methods and colour atlas of special stains and tissue artifacts, pp. 212-3. American Histolabs, Inc., Gaithersburg, MD.

Martinez, A. \& Kovacs, J. A. (1993). Development and characterization of a rapid screening assay for identifying antipneumocystis agents. Antimicrobial Agents and Chemotherapy 37, 1674-8.

Masur, H. \& Jones, T. C. (1978). The interaction in vitro of Pneumocystis carinii with macrophages and L-cells. Journal of Experimental Medicine 147, 157-70.

Masur, H., Lane, H. C., Kovacs, J. A., Allegra, C. J. \& Edman, J. C. (1989). Pneumocystis pneumonia: from bench to clinic. Annals of Internal Medicine 111, 813-26.

Pesanti, E. L. (1980). In vitro effects of antiprotozoan drugs and immune serum on Pneumocystis carinii. Journal of Infectious Diseases 141, 775-80.

Pesanti, E. L. (1991). Interaction of cytokines and alveolar cells with Pneumocystis carinii in vitro. Journal of Infectious Diseases 163, 611-6.

Pifer, L. L., Pifer, D. D. \& Woods, D. R. (1983). Biological profile and response to anti-pneumocystis agents of Pneumocystis carinii in cell culture. Antimicrobial Agents and Chemotherapy 24, 674-8.

Powles, M. A., McFadden, D. C., Pittarelli, L. A. \& Schmatz, D. M. (1992). Mouse model for Pneumocystis carinii pneumonia that uses natural transmission to initiate infection. Infection and Immunity 60, 1397-1400.

Queener, S. F., Fujioka, H., Nishiyama, Y., Furkuawa, H., Bartlett, M. S. \& Smith, J. W. (1991). In vitro activities of acridone alkaloids against Pneumocystis carinii. Antimicrobial Agents and Chemotherapy 35, 337-79.

Roths, J. B., Marshall, J. D., Allen, R. D., Carlson, G. A. \& Sidman, C. L. (1990). Spontaneous Pneumocystis carinii pneumonia in immunodeficient mutant scid mice. American Journal of Pathology 136, 1173-86.

Roths, J. B., Smith, A. L. \& Sidman, C. L. (1993). Lethal exacerbation of Pneumocystis carinii pneumonia in severe combined immunodeficiency mice after infection by pneumonia virus of mice. Journal of Experimental Medicine 177, 1193-8.

Roths, J. B. \& Sidman, C. L. (1992). Both immunity and hyperresponsiveness to Pneumocystis carinii result from transfer of $\mathrm{CD4}^{+}$but not $\mathrm{CD8}^{+} \mathrm{T}$ cells into severe combined immunodeficiency mice. Journal of Clinical Investigation 90, 673-8.

Roths, J. B. \& Sidman, C. L. (1993). Single and combined humoral and cell-mediated immunotherapy of Pneumocystis carinii pneumonia in immunodeficient scid mice. Infection and Immunity 61, 1641-9.

Schmatz, D. M., Powles, M. A., McFadden, D. C., Pittarelli, L., Baalkovec, J., Hammond, M. et al . (1992). Antipneumocystis activity of water-soluble lipopeptide L-693,989 in rats. Antimicrobial Agents and Chemotherapy 36, 1964-70.

Sethi, K. K. (1992). Multiplication of human-derived Pneumocystis carinii in severe combined immunodeficient (SCID) mice. Experientia 48, 63-7.

Shultz, L. D., Schweitzer, P. A., Hall, E. J., Sundberg, J. P., Taylor, S. \& Walzer, P. D. (1989). 
Pneumocystis carinii pneumonia in scid/scid mice. Current Topics in Microbiology and Immunology 152, 243-9.

Smulian, A. G. \& Walzer, P D. (1992). The biology of Pneumocystis carinii. Critical Reviews in Microbiology 18, 191-26.

Stevens, R. C., Laizure, S. C., Williams, C. 1. \& Stein, D. S. (1991). Pharmacokinetics and adverse effects of $20-\mathrm{mg} / \mathrm{kg} /$ day trimethoprim and $100-\mathrm{mg} / \mathrm{kg} /$ day sulfamethoxazole in healthy adult subjects. Antimicrobial Agents and Chemotherapy 35, 1884-90.

Sundberg, J. P., Burnstein, T., Shultz, L. D. \& Bedigian, H. (1989). Identification of Pneumocystis carinii in immunodeficient mice. Laboratory Animal Science 39, 213-8.

Taylor, M. B., Phillips, M. \& Easmon, C. S. F. (1992). Opsonophagocytosis of Pneumocystis carinii. Journal of Medical Microbiology 36, 223-8.

Telzak, E. E., Cote, R. J., Gold, J. W. M., Campbell, S. W. \& Armstrong, D. (1990). Extrapulmonary Pneumocystis carinii infections. Reviews of Infectious Diseases 12, 380-6.

Ueda, K., Goto, Y., Yamazaki, S. \& Fujiwara, K. (1977). Chronic fatal pneumocystosis in nude mice. Japanese Journal of Experimental Medicine 47, 475-82.

van den Broek, P. J. (1989). Antimicrobial drugs, microorganisms, nnd phagocytes. Reviews of Infectious Diseases 11, 213-45.

Walzer, P. D., Foy, J., Steele, P., Kim, C. K., White, M., Klein, R. S. et al. (1992a). Activities of antifolate, antiviral, and other drugs in immunosuppressed rat model of Pneumocystis carinii pneumonia. Antimicrobial Agents and Chemotherapy 36, 1935-42.

Walzer, P. D., Foy, J., Steele, P. \& White, M. (1992b). Treatment of experimental pneumocystosis: review of 7 years of experience and development of a new system for classifying antimicrobial drugs. Antimicrobial Agents and Chemotherapy 36, 1943-50.

Walzer, P. D., Kim, C. K., Linke, M. J., Pogue, C. L., Huerkamp, M. J., Chrisp, C. E. et al. (1989). Outbreaks of Pneumocystis carinii pneumonia in colonies of immunodeficient mice. Infection and Immunity 57, 62-70.

Walzer, P. D., Powell, R. D.\& Yoneda, K. (1979a). Experimental Pneumocystis carinii pneumonia in different strains of cortisonized mice. Infection and Immunity 24, 939-47.

Walzer, P. D., Rutledge, M. E., Yoneda, K. \& Stahr, B. J. (1979b). Pneumocystis carinii: new separation method from lung tissue. Experimental Parasitology 47, 356-68.

Walzer, P. D., Schnelle, V., Armstrong, D. \& Rosen, P. P. (1977). Nude mouse: a new experimental model for Pneumocystis carinii infection. Science 197, 177-9.

(Received 19 July 1994; accepted 31 January 1995) 